\title{
Comparison and optimization of ancient DNA extraction
}

\author{
Nadin Rohland and Michael Hofreiter
}

BioTechniques 42:343-352 (March 2007)

doi 10.2144/000112383

\begin{abstract}
Ancient DNA analyses rely on the extraction of the tiny amounts of DNA remaining in samples that are hundreds to tens of thousands of years old. Despite the critical role extraction efficiency plays in this field of research, no study has comprehensively compared ancient DNA extraction techniques to date. There are a wide range of methods currently in use, which rely on such disparate principles as spin columns, alcohol precipitation, or binding to silica. We have compared a number of these methods using quantitative PCR and then optimized each step of the most promising method. We found that most chemicals routinely added to ancient DNA extraction buffers do not increase, and sometimes even decrease, DNA yields. Consequently, our optimized method uses a buffer consisting solely of EDTA and proteinase K for bone digestion and binding DNA to silica via guanidinium thiocyanate for DNA purification. In a comparison with published methods, this minimalist approach, on average, outperforms all other methods in terms of DNA yields as measured using quantitative PCR. We also found that the addition of bovine serum albumin (BSA) to the PCR helps to overcome inhibitors in ancient DNA extracts. Finally, we observed a marked difference in the performance between different types of DNA polymerases, as measured by amplification success.
\end{abstract}

\section{INTRODUCTION}

Although founded more than 20 years ago (1), the field of ancient DNA research continues to grow (2) and expand into new areas $(3,4)$. Ancient DNA research shares a common problem with forensics and other approaches requiring analyses of museum and non-invasively collected specimens; the amount of endogenous DNA available in the samples is often limited. Thus, extraction techniques that retrieve as much DNA as possible from a specimen are of crucial importance. A wide range of techniques has been published to date (5-9), all of which aim to maximize DNA yields, while minimizing the co-extraction of PCR inhibitors $(7,10)$. However, rather than being the product of systematic investigations, these techniques are often founded upon untested assumptions regarding the state of the various biomolecules in ancient samples, including proteins and the DNA itself. Although limited comparisons between different methods (11-13) have been made, no comprehensive study comparing the major protocols in use has been published to date.

We tested several published extraction methods on a number of Pleistocene cave bear bones and teeth using quantitative PCR. We also evaluated the effect of various chemicals added to the extraction buffer and investigated factors such as extraction temperature and extraction duration. We also assessed the performance of PCR amplification both with and without bovine serum albumin (BSA) (14). Finally, we measured the ability of commercially available DNA polymerases to successfully amplify ancient DNA.

\section{MATERIALS AND METHODS}

\section{Samples}

We used eight cave bear bone samples and two cave bear teeth, originating from nine different caves in Austria, Switzerland, Slovenia, Croatia, Russia, and Germany (see Supplementary Table $\mathrm{S} 1$ available online at www.BioTechniques.com). As cave bears (Ursus spelaeus) became extinct at the end of the Pleistocene (15), all samples are of Pleistocene age and most likely older than 20,000 years. Three specimens were radiocarbon dated using accelerator mass spectroscopy, resulting in age estimates of between 27,000 and 44,000 years $(3,5)$.

\section{DNA Extraction Methods}

Initially we tested two published extraction methods $(5,8)$, one slightly modified method, and three commercially available DNA extraction kits, using three of the above-described samples and compared the DNA yields using quantitative PCR. These methods include the basic principles mostly used for ancient DNA purification, ultrafiltration via spin columns, and binding to silica. We also used spin columns combined with an extraction buffer used in the published silica method (5) in order to disentangle the processes of DNA solution and purification (for detailed information see the supplementary material). 


\section{Research Reports}

Table 1. Results of Quantitative PCR Comparing Different Extraction Methods Using 40 mg Sample Powder

\begin{tabular}{|c|c|c|c|c|}
\hline & 323 & 330 & 748 & Sample ID \\
\hline \multirow[t]{2}{*}{ Extraction Method } & \multicolumn{4}{|c|}{ Copy Number per Gram } \\
\hline & \multicolumn{3}{|c|}{ Relative to Best Method } & Average \\
\hline \multirow[t]{2}{*}{ Silica } & 0 & 1953 & 206 & \\
\hline & 0 & 1 & 0.07 & 0.36 \\
\hline \multirow[t]{2}{*}{ Centricon } & 0 & 0 & 2894 & \\
\hline & 0 & 0 & 1 & 0.33 \\
\hline \multirow[t]{2}{*}{ Phenol/chloroform } & 0 & 399 & 363 & \\
\hline & 0 & 0.2 & 0.13 & 0.11 \\
\hline \multirow[t]{2}{*}{ DNeasy tissue kit } & 16 & 0 & 173 & \\
\hline & 0.03 & 0 & 0.06 & 0.03 \\
\hline \multirow[t]{2}{*}{ All-tissue DNA kit } & 72 & 19 & 599 & \\
\hline & 0.12 & 0.01 & 0.21 & 0.11 \\
\hline \multirow[t]{2}{*}{ DNA IQ system } & 626 & 13 & 2872 & \\
\hline & 1 & 0.01 & 0.99 & 0.67 \\
\hline \multicolumn{5}{|c|}{$\begin{array}{l}\text { Absolute copy numbers per gram of powder are shown, together with relative numbers compared with } \\
\text { the best performing method in this test series, calculated separately for each sample. None of the ex- } \\
\text { traction methods was significantly worse }(P<0.05) \text { compared with the best performing method (DNA IQ } \\
\text { system) using a paired Student's } t \text {-test. Silica refers to the published method from Reference 5. Centricon } \\
\text { uses the same extraction buffer, but purification and concentration were completed using Centricon }{ }^{\circledR} \text { YM- } \\
30 \text { filter devices (Millipore, Billerica, MA, USA). Phenol/chloroform refers to Reference 8. DNeasy tissue } \\
\text { kit was used according to the user-developed protocol: Isolation of genomic DNA from compact bone us- } \\
\text { ing the DNeasy tissue kit (Qiagen). All-tissue DNA kit was used according to the provided protocol: DNA- } \\
\text { Präparationen aus Knochen with All-tissue DNA-kit (GEN-IAL). The DNA IQ system was used according } \\
\text { to the provided protocol: Bone extraction protocol to be used with the DNA IQ system (Promega). }\end{array}$} \\
\hline
\end{tabular}

To assess the effect of modifying a number of factors, including changing the chemicals added to the extraction buffer, varying incubation time, and fluctuating incubation temperature, we selected one method (5) that produced high DNA yields, demanded comparatively little working time, and allowed for systematic modification. For this assessment, all components and their concentrations need to be known. We used three (or only two at the end of the test series) cave bear samples when applying this method, while optimizing individual factors. We then compared DNA yields to the best performing method in each test series to determine the relative performance of each $t$-tests on each series. In cases where we found no significant difference between methods - a common finding attributable to the stochastic nature of DNA yields from ancient bone-we method and applied paired Student's continued with the method that yielded the best results, provided that it did not substantially increase the workload and costs compared with other statistically indistinguishable methods.

Finally, we compared the DNA yields obtained from the optimized extraction method with several established methods. We used eight different cave bear samples in duplicate. All major principles of DNA purification (alcohol precipitation following phenol/chloroform extraction, ultrafiltration using spin columns, and binding to silica) were represented. We tested each extract's degree of inhibition with quantitative PCR using a defined amount of modern human DNA spiked with ancient extracts (16). We calculated the extent of inhibition from both the exactly measured number of human DNA template and from the efficiency of each individual quantitative PCR with and without ancient DNA extract (for details see the supplementary information). For each test we used a homogenized powder obtained by grinding the samples using a Spex 6750 freezer mill (Spex SamplePrep, Metuchen, NJ, USA) to avoid variation due to different DNA preservation in different parts of the bones. Blank controls were performed throughout all experimental steps.

\section{Quantitative PCR}

To assess DNA yields we used a probe-based quantitative PCR system (ABI PRISM ${ }^{\circledR 7700 ; ~ A p p l i e d ~}$ Biosystems, Foster City, CA, USA). We used a dilution series of a PCR product

Table 2. Results of Quantitative PCR Comparing the Two Best Performing Extraction Methods Using 200 mg Sample Powder

\begin{tabular}{|c|c|c|c|c|c|c|c|c|c|c|c|c|c|c|c|}
\hline & \multicolumn{3}{|c|}{323} & \multicolumn{3}{|c|}{330} & \multicolumn{3}{|c|}{748} & \multicolumn{3}{|c|}{891} & \multicolumn{3}{|c|}{ Sample ID } \\
\hline \multirow{2}{*}{$\begin{array}{l}\text { Extraction } \\
\text { Method }\end{array}$} & \multicolumn{15}{|c|}{ Copy Number per Gram } \\
\hline & \multicolumn{12}{|c|}{ Relative to Best Method } & \multicolumn{3}{|c|}{ Average } \\
\hline \multirow[t]{2}{*}{ Silica } & 0 & 0 & 0 & 0 & 70 & 35 & 36 & 151 & 93 & 22 & 11065 & 5555 & & & \\
\hline & 0 & 0 & 0 & 0 & 1 & 0.21 & 0.2 & 1 & 1 & 0.01 & 1 & 1 & $0.05^{*}$ & 0.75 & 0.4 \\
\hline $\begin{array}{l}\text { DNA IQ } \\
\text { system }\end{array}$ & 1 & 1 & 1 & 1 & 0 & 1 & 1 & 0 & 0.96 & 1 & 0.04 & 0.23 & 1 & 0.26 & 0.63 \\
\hline
\end{tabular}




\section{Research Reports}

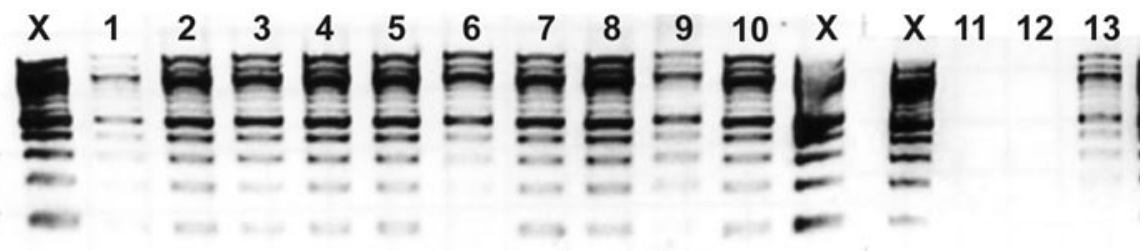

Figure 1. Comparison of various binding salts. Comparison of the binding efficiency of various salts using a DNA size marker (100-bp DNA ladder; New England Biolabs, Ipswich, MA, USA). X indicates lanes on which the DNA amount originally bound to silica was loaded corresponding to $100 \%$ recovery. Lane 1, saturated $\mathrm{KH}_{2} \mathrm{PO}_{4}$; lane 2, saturated $\mathrm{NaCl}$; lane 3, saturated $\mathrm{NaI}$; lane 4, $5 \mathrm{M} \mathrm{NaClO}_{4}$; lane 5, $5 \mathrm{M} \mathrm{GuSCN}$; lane 6, saturated $\mathrm{NH}_{4} \mathrm{SO}_{4}$; lane 7, saturated $\mathrm{CsCl}$; lane 8, saturated $\mathrm{KCl}$; lane 9, saturated $\mathrm{MgSO}_{4}$; lane 10, saturated $\mathrm{GuCl}$; lane 11, saturated $\mathrm{NaAc}$; lane 12, saturated $\mathrm{NH}_{4} \mathrm{Ac}$; lane 13, old discolored saturated NaI. obtained previously as a standard. Its DNA concentration was measured via UV absorption using a NanoDrop ${ }^{\circledR}$ ND1000 spectrophotometer (NanoDrop Technologies, Wilmington, DE, USA). As measuring DNA concentrations is only possible with limited precision and concentrations of standard dilution series change due to storage, we evaluated, aside from the absolute DNA yields, the relative performance of the methods within each run. This approach was also used because ancient DNA yields may vary between extracts taken from different samples of the same bone, even when using the same extraction method (2). Such differences are likely attributable to heterogeneity within bones. We attempted to minimize such effects by using a homogenous powder.

We assessed the concentration of a 110-bp piece (including primers) of mitochondrial DNA from the $12 \mathrm{~S}$ ribosomal RNA (rRNA) gene. In all tests we only accepted quantitative PCR runs for which the correlation curve for the three replicates of the standard gave an $R^{2}$ value of at least $96 \%$, although in $73 \%$ of the runs it was above $98 \%$. We performed duplicate, and for the final comparison triplicate, measurements for each dilution step of each individual extraction to minimize errors caused by stochastic variation.

\section{Measuring PCR Performance}

To investigate the effect of BSA on PCR performance, we compared amplification success from a constant concentration of five cave bear extracts using AmpliTaq Gold ${ }^{\circledR}$ polymerase (Applied Biosystems), varying in concentration from 1 to $0.1 \mathrm{U}$ in 2-fold steps both in the presence and absence of $1 \mathrm{mg} / \mathrm{mL}$ BSA. The efficacy of different commercial polymerases (see Table 7) was tested using a dilution of an ancient DNA extract to the point at which AmpliTaq Gold polymerase yielded an amplification product in approximately $50 \%$ of the amplification attempts. The success rate of each of the polymerases was evaluated in 43 amplification reactions.

\section{RESULTS}

\section{Initial Comparison}

The initial comparison of six extraction methods showed large differ- ences both within and among methods, but with no consistent picture. We attribute this result to our use of only approximately 40-mg samples (Table 1 and see also Supplementary Table S2a for standard deviations). Therefore, we chose two methods that produced, on average, the highest relative copy numbers and required comparatively little processing time. Using $200 \mathrm{mg}$ sample material, these two methods differed little when the pooled data of the original and dilution step were compared (Table 2). However, when considering only the 1:10 dilution, the method that performed best by yielding the most amplifiable DNA was an extraction based on digestion of the sample powder in a buffer containing EDTA, proteinase $\mathrm{K}$, dithiothreitol (DTT), polyvinylpyrrolidone (PVP), $\mathrm{N}$-phenacyl thiazolium bromide (PTB; synthesized according to Reference 17), and $\mathrm{N}$-lauroyl-sarcosine sodium salt (sarcosyl) (5) and purifying the DNA by binding to silica in the presence of high concentrations of guanidinium thiocyanate (GuSCN). We give a greater weight to the results obtained from the 1:10 dilution, assuming that in the presence of different levels of inhibition, the dilution is more likely to yield an unbiased measure of DNA quantity. Moreover, since we do not know the composition of the different

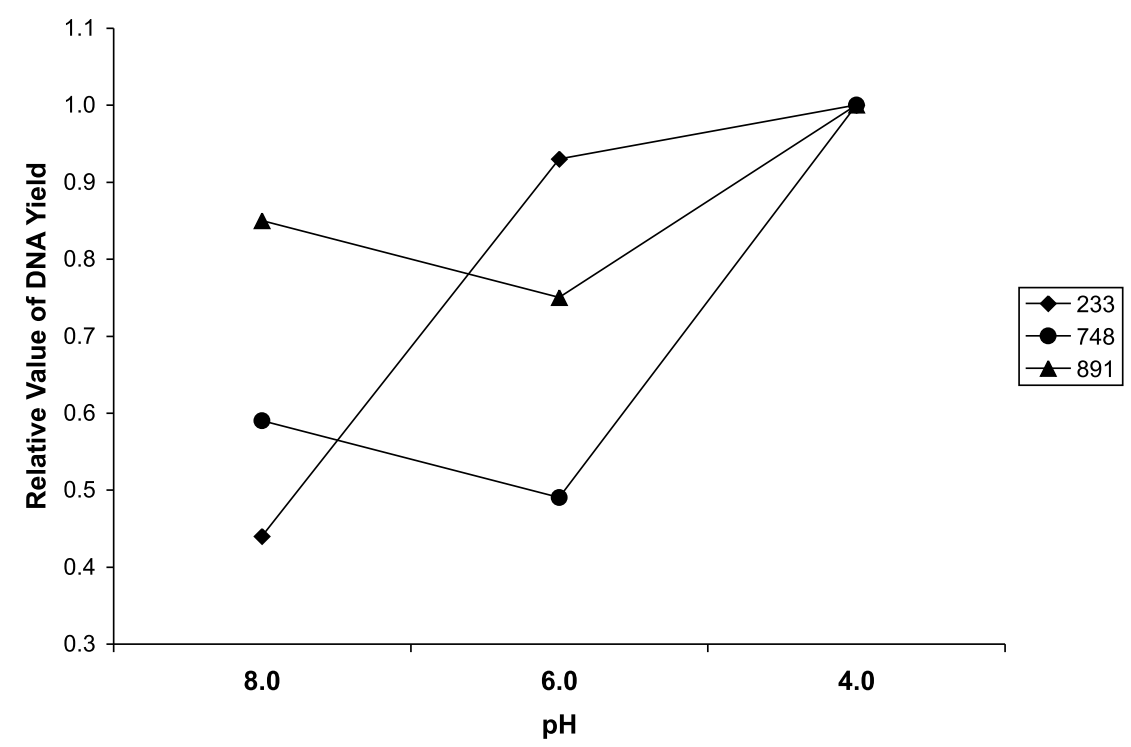

Figure 2. Dependency of DNA recovery on $\mathbf{p H}$. Relative values of DNA yields are plotted against the corresponding $\mathrm{pH}$ of the GuSCN binding buffer, including the silica suspension and extraction buffer of each respective sample (see also Supplementary Table S12). 


\section{Research Reports}

buffers used in the DNA IQ kit (Promega, Madison, MI, USA), there is little room for modification. For these two reasons, we continued using the silica method.

\section{Optimization of Silica-Based DNA Purification}

The method using an EDTA-based buffer for bone powder digestion and GuSCN/silica for DNA purification has evolved $(5,6,17-19)$ from the initial silica extraction method described by Boom et al. (20). However, its performance has not been tested in comparison to other methods, and it is not known whether any of the modifications improves DNA yields, when compared with those obtained using the initial method by Boom.

In the first comparison, we tested DNA yields both in the presence and absence of different surfactants in the extraction solution. Surprisingly, few of the chemicals had a positive effect on DNA yields, and some commonly used in ancient DNA extraction, such as sarcosyl and other ionic surfactants, even had a negative effect (Table 3). In fact, none of the surfactants improved DNA yields substantially, although some non-ionic surfactants (e.g., Triton ${ }^{\circledR}-\mathrm{X}$ 100) show slightly better results. However, this could be a stochastic effect, as one sample yielded only low copy numbers and the method including this surfactant was not significantly better than that omitting it.

After removing the surfactant from the extraction buffer, we tested whether the incubation time and temperature of bone powder in digestion buffer had any effect on the DNA yield (Table 4). Both different incubation temperatures (room temperature to $56^{\circ} \mathrm{C}$ ) and incubation times ( $1 \mathrm{~h}$ to 4 days) had only minor effects on DNA yields. The degree of digestion, however, varied considerably, with the shortest incubation period showing no visible reduction in the amount of bone powder, while the longest or warmest incubation period resulted in complete digestion. Due to both the slightly higher yields and convenient handling, we performed the remaining experiments using an overnight incubation period at room temperature.
In the next experiment, we tested the presence and absence of all other ingredients in the extraction buffer in all possible combinations (Supplementary Tables S5, a-d). As with surfactants, most chemicals did not have a positive effect. The overall ineffectiveness of reducing agents is particularly striking (Supplementary Table S5c and S8). It should be noted, however, that one reducing agent, namely 5,5'-dithiobis(2-nitrobenzoic acid) or Ellman's Reagent, had a limited positive effect on DNA yield in our experiments (Supplementary Table S8). However, this was the case for only one of the three samples tested. Buffering the extraction solution with $0.05 \mathrm{M}$ Tris, $\mathrm{pH}$ 8.0, did not have a positive effect (Supplementary Table S6). The only reagents that showed a clear positive effect on DNA yields were EDTA in a minimum concentration of $0.2 \mathrm{M}$ (Supplementary Table S7) and proteinase K.

We also found that grinding the samples into a fine powder is crucial.
In a comparison of samples ground to a fine powder using a freezer mill versus samples ground to pieces one to a few millimeters in diameter using mortar and pestle, we found that the fine powder produced higher yields (Supplementary Table S9). When we repeated the extraction with the remaining material until almost all material was digested $\left(2 \mathrm{~h}\right.$ at $\left.56^{\circ} \mathrm{C}\right)$, the fine powder only yielded trace amounts of DNA. In contrast, the coarse powder yielded DNA amounts comparable to those measured in the first extraction. Thus, if samples can only be ground coarsely, a 2-h digestion period at $56^{\circ} \mathrm{C}$ following overnight incubation at room temperature should increase DNA yields.

Aside from DNA release, the second critical step in DNA extraction is the purification process. Although it is widely assumed that chaotropic salts are necessary for this process $(20,21)$, we also used a number of nonchaotropic salts. Remarkably, most of the salts we used were effective in binding

Table 3. Results of Quantitative PCR Comparing Different Surfactants in the Extraction Buffer

\begin{tabular}{|c|c|c|c|c|}
\hline & 330 & 748 & 891 & Sample ID \\
\hline \multirow[t]{2}{*}{ Surfactant } & \multicolumn{3}{|c|}{ Copy Number per Gram } & \\
\hline & \multicolumn{3}{|c|}{ Relative to Best Method } & Average \\
\hline \multirow[t]{2}{*}{$1 \%$ Tween $^{\circledR} 20$} & 94 & 11,496 & 585,456 & \\
\hline & 0.07 & 0.67 & 1 & 0.58 \\
\hline \multirow[t]{2}{*}{ 1\% Triton-X 100} & 982 & 13,266 & 443,401 & \\
\hline & 0.78 & 0.78 & 0.76 & 0.77 \\
\hline \multirow[t]{2}{*}{$0.5 \% \mathrm{~N}$-lauryl-sarcosine } & 7 & 4893 & 65,566 & \\
\hline & 0.01 & 0.29 & 0.11 & $0.17^{*}$ \\
\hline \multirow[t]{2}{*}{$0.5 \%$ SDS } & 0 & 5207 & 89,645 & \\
\hline & 0 & 0.30 & 0.15 & $0.15^{\star}$ \\
\hline \multirow[t]{2}{*}{$1 \%$ CTAB } & 1263 & 1839 & 13,453 & \\
\hline & 1 & 0.11 & 0.02 & 0.38 \\
\hline \multirow[t]{2}{*}{2 M Urea } & 249 & 3577 & 277,575 & \\
\hline & 0.20 & 0.21 & 0.47 & $0.29^{\star}$ \\
\hline \multirow[t]{2}{*}{$2 \mathrm{M} \mathrm{GuCl}$} & 23 & 10,322 & 355,536 & \\
\hline & 0.02 & 0.60 & 0.61 & 0.41 \\
\hline \multirow[t]{2}{*}{ Without } & 72 & 17,108 & 450,806 & \\
\hline & 0.06 & 1 & 0.77 & 0.61 \\
\hline \multicolumn{5}{|c|}{$\begin{array}{l}\text { Absolute copy numbers per gram of powder are shown together with relative numbers compared with } \\
\text { the best performing method shown separately for each sample in this test series. Surfactants performing } \\
\text { worse at a statistically significant level as compared with the best performing one ( } 1 \% \text { Triton-X 100) are } \\
\text { indicated by an asterisk ( }{ }^{*}, P<0.05 \text {, paired Student's } t \text {-test). SDS, sodium dodecyl sulfate; CTAB, cety } \\
\text { trimethyl ammonium bromide. }\end{array}$} \\
\hline
\end{tabular}




\section{Research Reports}

Table 4. Results of Quantitative PCR Comparing Different Times and Temperatures of Incubation of Bone Powder in the Extraction Buffer

\begin{tabular}{|c|c|c|c|c|}
\hline & 233 & 748 & 891 & Sample ID \\
\hline \multirow{2}{*}{$\begin{array}{l}\text { Temperature and } \\
\text { Duration of Incubation }\end{array}$} & \multicolumn{4}{|c|}{ Copy Number per Gram } \\
\hline & \multicolumn{3}{|c|}{ Relative to Best Method } & Average \\
\hline \multirow{2}{*}{$\begin{array}{l}56^{\circ} \mathrm{C} \\
1 \mathrm{~h}\end{array}$} & 0 & 5771 & 113,569 & \\
\hline & 0 & 0.65 & 0.41 & 0.35 \\
\hline \multirow{2}{*}{$\begin{array}{l}37^{\circ} \mathrm{C} \\
1 \mathrm{~h}\end{array}$} & 120 & 8868 & 97,507 & \\
\hline & 0.06 & 1 & 0.35 & 0.47 \\
\hline \multirow{2}{*}{$\begin{array}{l}37^{\circ} \mathrm{C} \\
\text { Overnight }\end{array}$} & 0 & 7508 & 172,780 & \\
\hline & 0 & 0.85 & 0.63 & 0.49 \\
\hline \multirow{2}{*}{$\begin{array}{l}\text { Room temperature } \\
\text { Overnight }\end{array}$} & 92 & 6779 & 275,869 & \\
\hline & 0.05 & 0.76 & 1 & 0.6 \\
\hline \multirow{2}{*}{$\begin{array}{l}\text { Room temperature } \\
4 \text { days }\end{array}$} & 1876 & 1443 & 139,473 & \\
\hline & 1 & 0.16 & 0.51 & 0.56 \\
\hline \multirow{2}{*}{$\begin{array}{l}\text { Room temperature } \\
4 \text { days }(+\mathrm{PK})\end{array}$} & 356 & 2129 & 128,746 & \\
\hline & 0.19 & 0.24 & 0.47 & 0.3 \\
\hline \multicolumn{5}{|c|}{$\begin{array}{l}\text { Absolute copy numbers per gram of powder are shown, with relative numbers compared with the best } \\
\text { performing method in this test series. None of the different incubation conditions were significantly worse } \\
\text { compared with the best performing one (room temperature, overnight) according to a paired Student's } \\
t \text {-test }(P<0.05) \text {. (+PK), indicates the extra addition of proteinase } \mathrm{K} \text { after } 2 \text { days. }\end{array}$} \\
\hline
\end{tabular}

a DNA size marker to a silica matrix, which allowed for later recovery of the DNA (Figure 1). We then tested the most promising salts on ancient bone samples. Although not statistically significant, $\mathrm{NaCl}$ performed better than all tested chaotropic salts, and washing the silica pellet twice with
GENECLEAN $^{\circledR}$ New Wash solution (Qbiogene, Irvine, CA, USA) yielded higher copy numbers than washing only once (see Table 5).

Finally, for the silica-based DNA purification method, we measured the effect of varying the silica suspension age, the $\mathrm{pH}$ at the binding step, the

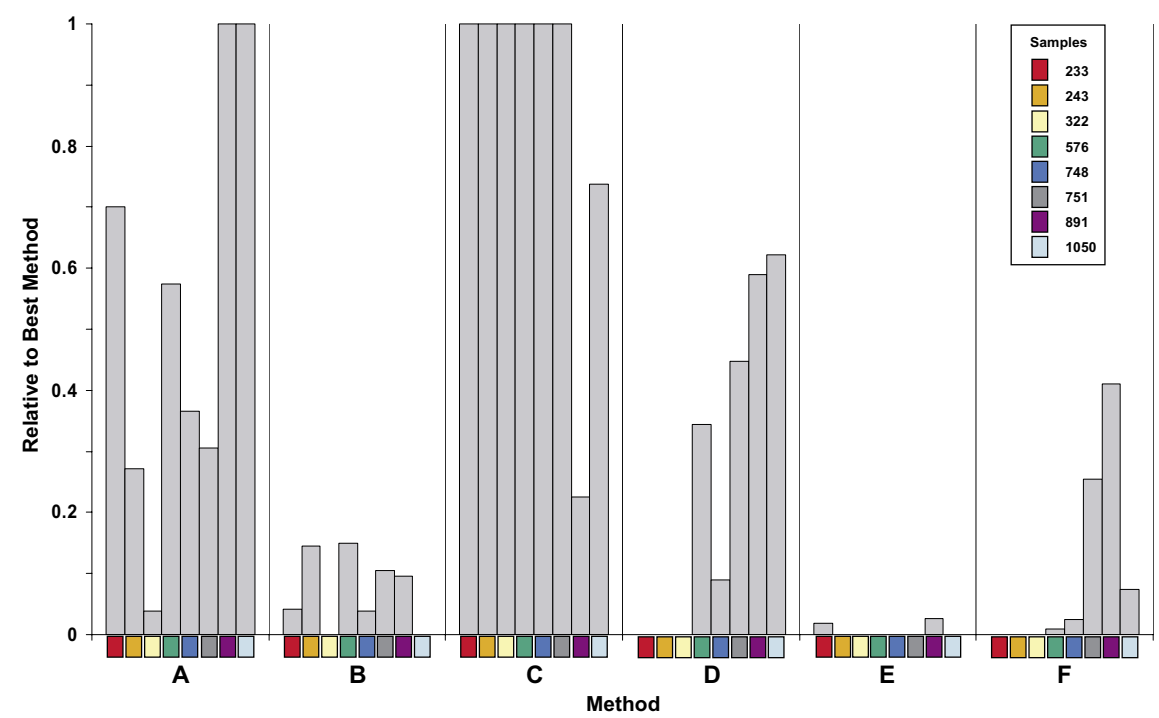

Figure 3. Relative values of the final comparison. Copy number values relative to the copy number of the best performing method for each of the eight samples (see Supplementary Table S17). A, silica (5); $\mathrm{B}$, modified silica, $\mathrm{NaCl}$; C, modified silica, GuSCN; D, phenol chloroform (8); E, ethanol precipitation (7); F, Qiagen kit. amount of silica in suspension, the binding time, the silica suspension preparation technique, and alternatives to the commercial wash buffer. Although in some of the experiments, the improvement in copy number was negligible, it should be noted that silica suspension older than 1 month should not be used for samples containing very low copy numbers (Supplementary Table S11). The pH of the binding buffer had a significant impact on DNA yields (Figure 2 and Supplementary Table S12), with $\mathrm{pH}$ 4.0 producing the highest yields for all three samples. We also found that using more silica is better than using less (Supplementary Table S13). In addition, the incubation time for the binding step affected DNA yields; DNA yields increased as incubation time increased, up until $3 \mathrm{~h}$, when the effect leveled off (Supplementary Table S14). A slightly modified preparation protocol for the silica suspension resulted in slightly higher yields with a reduced preparation time $(5 \mathrm{~h}$ versus 2 days; see Supplementary Table S15). Alternative wash solutions worked as well as the commercially available one (New Wash) (Supplementary Table S16).

\section{Final Comparison}

After optimizing the various steps during the extraction process, we compared our original conditions (method A, silica) (5) with the modified method using two different binding solutions in the purification step (methods $\mathrm{B}, \mathrm{NaCl}$, and $\mathrm{C}, \mathrm{GuSCN}$ ), as well as with published methods using spin columns (method D, phenol chloroform) (8), ethanol precipitation (method E) (7), and a commercial kit (method F, DNeasy ${ }^{\circledR}$ tissue kit; Qiagen, Valencia, CA, USA; User-developed protocol: Isolation of genomic DNA from compact bone using the DNeasy tissue kit). For this comparison we used eight samples, with a duplicate extraction for each method. We tested the performance of each method both by amplifying ancient DNA in two dilution steps (1:10 and 1:50) using regular PCR immediately after each extraction and by using quantitative PCR in which all samples were tested simultaneously after 


\section{Research Reports}

one freeze-thaw step. In the direct PCR, three methods yielded similar results, all of which were based on binding to silica, either in the presence of GuSCN or $\mathrm{NaCl}$ (methods $\mathrm{A}, \mathrm{B}$, and $\mathrm{C}$ ). The other three methods gave significantly worse results (see Table 6).

However, in the quantitative comparison, the modified silica method using GuSCN as a binding buffer (method C) outperformed all other methods, except our original method, with statistical significance. Thus, for six samples, this modified method performed best (Supplementary Table S17) with either methods $A$ or D close behind. In two cases, method A performed best with methods $\mathrm{C}$ or $\mathrm{D}$ following. Methods B, E, and F always yielded poor results (Figure 3). As with the step-by-step improvement, we found highly variable copy numbers in some samples.

Finally, we assessed the extent to which the various extracts inhibit PCR. As shown in Supplementary Table S18, methods $\mathrm{A}$ and $\mathrm{C}$ showed no inhibition in any of the samples. All other methods

Table 5. Results of Quantitative PCR Comparing Different Salts for Binding DNA to Silica

\begin{tabular}{|c|c|c|c|c|}
\hline & 233 & 748 & 891 & Sample ID \\
\hline \multirow{2}{*}{$\begin{array}{l}\text { Salt } \\
\text { (Concentration) }\end{array}$} & \multicolumn{4}{|c|}{ Copy Number per Gram } \\
\hline & \multicolumn{3}{|c|}{ Relative to Best Method } & Average \\
\hline \multirow{2}{*}{$\begin{array}{l}\mathrm{KCl} \\
\text { (saturated, about 4.6 M) }\end{array}$} & 1222 & 147 & 82,566 & \\
\hline & 0.02 & 0.01 & 0.07 & $0.03^{*}$ \\
\hline \multirow{2}{*}{$\begin{array}{l}\mathrm{GuCl} \\
\text { (saturated, about } 22 \mathrm{M} \text { ) }\end{array}$} & 54,956 & 273 & 547,916 & \\
\hline & 0.99 & 0.03 & 0.49 & 0.50 \\
\hline \multirow{2}{*}{$\begin{array}{l}\text { GuSCNa } \\
(5 \mathrm{M})\end{array}$} & 55,522 & 3324 & 401,612 & \\
\hline & 1 & 0.34 & 0.36 & 0.57 \\
\hline \multirow{2}{*}{$\begin{array}{l}\text { GuSCNb } \\
(5 \mathrm{M})\end{array}$} & 6927 & 7920 & $1,088,570$ & \\
\hline & 0.12 & 0.80 & 0.96 & 0.63 \\
\hline \multirow{2}{*}{$\begin{array}{l}\mathrm{NaClO}_{4} \\
(5 \mathrm{M})\end{array}$} & 36,864 & 5510 & 436,263 & \\
\hline & 0.66 & 0.56 & 0.39 & 0.54 \\
\hline \multirow{2}{*}{$\begin{array}{l}\mathrm{NaCl} \\
\text { (saturated, about } 6 \mathrm{M} \text { ) }\end{array}$} & 40,266 & 9878 & 763,410 & \\
\hline & 0.73 & 1 & 0.68 & 0.80 \\
\hline \multirow{2}{*}{$\begin{array}{l}\text { Nal } \\
\text { (saturated, about } 12 \mathrm{M} \text { ) }\end{array}$} & 631 & 6764 & $1,128,573$ & \\
\hline & 0.01 & 0.68 & 1 & 0.56 \\
\hline \multicolumn{5}{|c|}{$\begin{array}{l}\text { Absolute copy numbers per gram of powder and relative numbers compared with the best performing } \\
\text { method in this test series are shown. Significantly worse performing binding salts compared with the bes } \\
\text { performing one }(6 \mathrm{M} \mathrm{NaCl}) \text { are indicated by an asterisk }\left({ }^{*}, P<0.05 \text {, paired Student's } t \text {-test). The con }\right. \\
\text { centration of the binding buffer before addition of the extraction buffer and silica is shown in parenthesis } \\
\text { Two different washing procedures for GuSCN were performed. } \\
\text { aThe washing procedure was once with New Wash } \\
\text { bThe washing procedure was twice with New Wash. }\end{array}$} \\
\hline
\end{tabular}

A

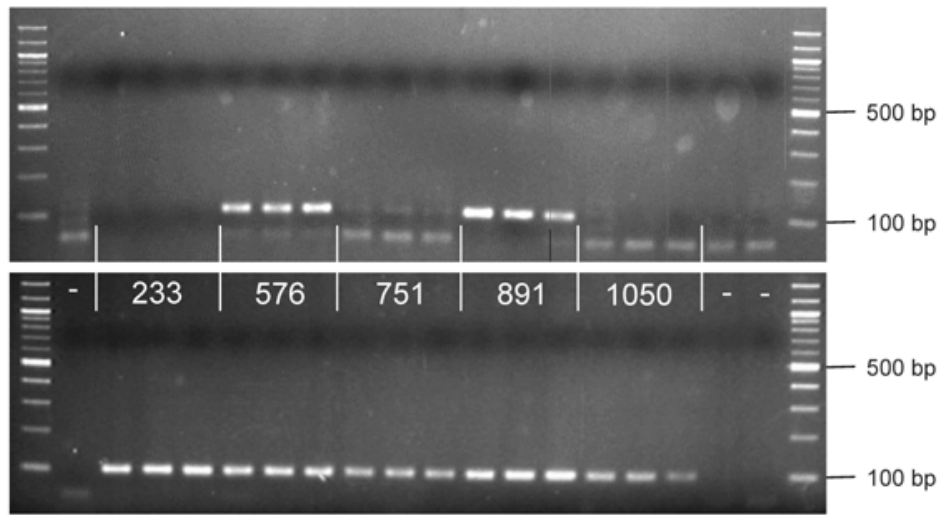

Figure 4. Positive effect of bovine serum albumin (BSA). Gel picture showing PCR performance of five different cave bear samples $(233,576,751,891,1050)$ in triplicate using 0.25 U AmpliTaq Gold both in the absence (A) and the presence (B) of $1 \mathrm{mg} / \mathrm{mL}$ BSA in the PCR. A 100-bp DNA ladder was loaded onto the first and last lane; -, indicates PCR negative control; the PCR product has a length of $103 \mathrm{bp}$. yielded at least some extracts inhibiting the PCR to varying extents. Method E showed a very low degree of inhibition as well, but this is not surprising, as this method yielded very little or no DNA (see Supplementary Table S17 and Figure 3).

\section{PCR Performance}

To investigate the effect of BSA, we used a 1:10 dilution of five cave bear DNA extracts and compared the amplification success of using decreasing amounts of Taq DNA polymerase in both the presence and absence of BSA in triplicate for each cave bear sample. BSA allowed positive amplifications in all PCRs using 0.25 U Taq DNA polymerase (Figure 4B), while 6 out of 15 were negative in the absence of BSA and 3 PCRs produced very faint products (Figure 4A). Using 0.1 U Taq DNA polymerase per PCR, in the presence of BSA, 12 out of 15 PCRs yielded products of the expected size (data not shown), while no PCR product was visible in the absence of BSA. Thus, we recommend the use of BSA in a final concentration of 1 $\mathrm{mg} / \mathrm{mL}$ in any PCR using dirty DNA and a minimum of $0.25 \mathrm{U}$ Taq DNA polymerase.

Finally, we compared the amplification efficacy of 11 commercially available DNA polymerases. We found the highest amplification success for polymerase No. I, with polymerases Nos. II-VII yielding results not significantly worse (Table 7). The other polymerases produced results that were significantly worse, and sometimes no amplification product was obtained at all in 43 trials. As amplification products often need to be cloned in ancient DNA studies (2), a second criterion for suitability of polymerases for use in ancient DNA studies is the 
Table 6. Success of Conventional PCR Amplification Using Two Different Dilutions (1:10 and 1:50) of Eight Ancient Cave Bear Samples, Extracted with Each Method in Duplicate

\begin{tabular}{|c|c|c|c|c|c|c|c|c|c|c|c|c|}
\hline \multirow{2}{*}{$\begin{array}{l}\text { Extraction Method } \\
\text { Sample ID }\end{array}$} & \multicolumn{2}{|c|}{$\begin{array}{c}\text { A } \\
\text { Silica }\end{array}$} & \multicolumn{2}{|c|}{$\begin{array}{c}\text { B } \\
\text { Modified } \\
\text { Silica-NaCl }\end{array}$} & \multicolumn{2}{|c|}{$\begin{array}{c}\text { C } \\
\text { Modified } \\
\text { Silica-GuSCN }\end{array}$} & \multicolumn{2}{|c|}{$\begin{array}{c}\text { D } \\
\text { Phenol/ } \\
\text { Chloroform }\end{array}$} & \multicolumn{2}{|c|}{$\begin{array}{c}\text { E } \\
\text { Ethanol } \\
\text { Precipitation }\end{array}$} & \multicolumn{2}{|c|}{$\begin{array}{c}\text { F } \\
\underset{\text { Qiagen }}{\text { Kit }}\end{array}$} \\
\hline & $1: 10$ & $1: 50$ & $1: 10$ & $1: 50$ & $1: 10$ & $1: 50$ & $1: 10$ & $1: 50$ & $1: 10$ & $1: 50$ & $1: 10$ & $1: 50$ \\
\hline 233.1 & + & + & + & + & + & + & + & + & + & - & - & - \\
\hline 233.2 & + & + & + & + & + & + & - & + & + & + & - & - \\
\hline 322.1 & + & + & - & + & + & - & + & - & - & - & - & - \\
\hline 322.2 & + & + & - & - & + & - & - & - & - & - & - & - \\
\hline 576.1 & + & + & + & + & + & $(+)$ & + & + & - & - & + & + \\
\hline 576.2 & + & + & + & + & + & + & + & + & - & $(+)$ & - & + \\
\hline 751.2 & + & + & + & - & - & + & + & - & $(+)$ & - & + & - \\
\hline 891.1 & + & + & + & + & + & + & + & + & + & $(+)$ & + & + \\
\hline 891.2 & + & + & + & + & + & + & + & + & + & $(+)$ & + & + \\
\hline 1050.1 & + & + & + & + & + & + & + & + & - & - & $(+)$ & + \\
\hline 1050.2 & + & + & + & + & + & - & + & + & - & - & $(+)$ & $(+)$ \\
\hline$\Sigma$ & \multicolumn{2}{|c|}{$28 / 32$} & \multicolumn{2}{|c|}{$26 / 32$} & \multicolumn{2}{|c|}{$25 / 32$} & \multicolumn{2}{|c|}{$20 / 32^{*}$} & \multicolumn{2}{|c|}{$9 / 32^{*}$} & \multicolumn{2}{|c|}{$13 / 32^{*}$} \\
\hline
\end{tabular}

+ , indicates a distinct band on the agarose gel; $(+)$, indicates a faint band on the agarose gel; and -, indicates no band on the agarose gel. Significantly worse performing methods are indicated by an asterisk $\left({ }^{*}\right), P<0.05$, Fisher's exact test.

co-amplification of primer dimers or other artifacts. Both polymerases, Nos. I and III, perform rather poorly under this criterion, as compared with polymerase No. II, as both produce primer dimers under conditions in which polymerase No. II does not (Table 7). The former would therefore require either an additional reamplification step or purification of products of the correct size from the gel, thereby adding to the workload of the already labor-intensive process of ancient DNA research. Considering this factor, polymerase No. II is the most suitable polymerase for ancient DNA amplification.

\section{DISCUSSION}

In this report we present a step-bystep improvement of a silica-based ancient DNA extraction method. This approach improved ancient DNA yields compared with both the original and several other published methods.
Interestingly, most chemicals routinely added to ancient DNA extractions had no positive effect on DNA yields. None of the surfactants tested improved DNA yields as also shown elsewhere (22), although some nonionic surfactants (e.g., Triton-X 100) did not negatively impact the results. In hindsight, the results of the surfactant test are not as surprising as they may initially appear. Surfactants are used in modern DNA extractions in order to break up cell membranes. However, in specimens some 100 to tens of thousands of years old, even biomolecules such as DNA are fragmented into short pieces, and no structures only remotely reminiscent of intact cells are to be expected, except in rare, unusually well preserved specimens from permafrost environment (23). In fact, none of the chemicals added to the extraction buffer except for ETDA and proteinase $\mathrm{K}$, had a positive effect on DNA yields. In the case of PVP, this result may be explained by the fact that it is used in plant DNA extractions to remove inhibitors. However, the chemical nature of inhibitors in plant tissue and ancient bones, respectively, is likely to be different. More surprising is the ineffectiveness of PTB. Either crosslinks between DNA and other biomolecules are less common than sometimes assumed or they cannot be broken apart by PTB, although PTB has been shown to be effective in Pleistocene coprolite DNA extractions (17) and it has also been argued to improve extractions from Pleistocene bone specimens (24). DTT, because it is a widely used reagent, would be expected to facilitate protein digestion and assist in releasing DNA into solution, as well as possibly reduce cross-links between DNA and other biomolecules. However, it seems that proteinase $\mathrm{K}$ alone is sufficient for digesting bone proteins such as collagen, and cross-links between DNA and other biomolecules are either less common than sometimes assumed or cannot be broken by DTT. These 


\section{Research Reports}

Table 7. Comparison of Different Commercially Available DNA Polymerases Using 1 U Polymerase/PCR and Cave Bear DNA Extract as Template

\begin{tabular}{|c|c|c|c|c|c|}
\hline \multirow[t]{2}{*}{ No. } & \multirow[t]{2}{*}{ Enzyme Properties } & \multicolumn{2}{|c|}{ PCR Success } & \multicolumn{2}{|c|}{ Comment } \\
\hline & & (Absolute) & (\%) & (Strength of Bands) & (Primer Dimers) \\
\hline I & $\begin{array}{l}\text { Recombinant Taq DNA polymerase, } \\
\text { (SUPER Taq; HT Biotechnology)a }\end{array}$ & $31 / 43$ & 72 & $\begin{array}{l}\text { Faint to thick, } \\
\text { sometimes smears }\end{array}$ & Always \\
\hline II & $\begin{array}{l}\text { Inactive Taq DNA polymerase derived from a recombinant Taq DNA } \\
\text { polymerase (AmpliTaq Gold; Applied Biosystems) }\end{array}$ & $29 / 43$ & 67 & Thick & $\begin{array}{l}\text { When no or weak } \\
\text { product }\end{array}$ \\
\hline III & $\begin{array}{l}\text { Recombinant Taq DNA polymerase, Pyrococcus species GB-D ther- } \\
\text { mostable polymerase, and Platinum }{ }^{\circledR} \text { Taq antibody enzyme mixture } \\
\text { (Platinum Taq High Fidelity; Invitrogen) }\end{array}$ & $28 / 43$ & 65 & Faint to thick & Always \\
\hline IV & $\begin{array}{l}\text { Recombinant Taq DNA polymerase and Platinum Taq antibody } \\
\text { in a convenient SuperMix formulation (Platinum PCR SuperMix; } \\
\text { Invitrogen) }\end{array}$ & $26 / 43$ & 60 & Thick & $\begin{array}{l}\text { When no or weak } \\
\text { product }\end{array}$ \\
\hline V & $\begin{array}{l}\text { Recombinant Taq DNA polymerase, Platinum Taq antibody } \\
\text { and thermostable AccuPrime }{ }^{\mathrm{TM}} \text { proteins (AccuPrime Taq; Invitrogen) }\end{array}$ & $26 / 43$ & 60 & Thick & $\begin{array}{l}\text { When no or weak } \\
\text { product }\end{array}$ \\
\hline VII & $\begin{array}{l}\text { Recombinant Taq DNA polymerase and Platinum Taq antibody } \\
\text { (Platinum Taq; Invitrogen) }\end{array}$ & $22 / 43$ & 51 & Thick & $\begin{array}{l}\text { When no or weak } \\
\text { product }\end{array}$ \\
\hline VIII & $\begin{array}{l}\text { Recombinant Taq DNA polymerase and a proprietary thermostable } \\
\text { DNA polymerase with proofreading activity (SuperTaq }{ }^{\text {TM }} \text { Plus; } \\
\text { Ambion) }\end{array}$ & $20 / 43^{*}$ & 47 & Faint & Always \\
\hline IX & $\begin{array}{l}\text { Recombinant Taq DNA polymerase and a competitive } \\
\text { temperature-dependent polymerase inhibitor(HotMaster }{ }^{\mathrm{TM}} \text { Taq; } \\
\text { Eppendorf) }\end{array}$ & $12 / 43^{*}$ & 28 & Faint & Always \\
\hline$x$ & $\begin{array}{l}\text { Recombinant Taq DNA polymerase and a buffer additive stabilizing } \\
\text { the enzyme during PCR (MasterTaq }{ }^{\circledR} \text { kit; Eppendorf) }\end{array}$ & $0 / 43^{*}$ & 0 & - & Always \\
\hline XI & $\begin{array}{l}\text { Recombinant Taq strain YT1 DNA polymerase and BD TaqStart anti- } \\
\text { body (BD }{ }^{\text {TM }} \text { Taq Full HotStart DNA polymerase enzyme Mix; } \\
\text { BD Bioscience) }\end{array}$ & $0 / 43^{*}$ & 0 & Only smears & - \\
\hline
\end{tabular}

results coincide with results obtained for DNA extractions from forensic bones (22). The minor effect that both different incubation temperatures and incubation times have on DNA yields could possibly be explained by the fact that a greater DNA release at a higher temperature or longer incubation period may be compensated for by greater DNA degradation and/or reduced proteinase $\mathrm{K}$ activity (22). The fact that fine powder produced better results than coarsely ground material is most likely due to EDTA and proteinase $\mathrm{K}$ acting on a larger bone surface area.

The ideal method for purification and concentration of DNA should at the same time maximize DNA recovery and minimize the co-purification of PCR inhibitors. Binding to silica is widely used when clean DNA is required or samples contain large amounts of chemical substances of a poorly understood chemical nature but which are known to inhibit PCR $(6,20,22)$. Usually, chaotropic salts are used in order to bind DNA to a silica matrix $(20,21)$, a process still not fully understood, but most likely resulting from the dehydration of both DNA and silica surfaces and hydrophobic forces acting under high salt concentrations $(21,25)$. As several nonchaotropic salts are much cheaper than chaotropic salts, such as GuSCN or NaI, we tested, among others, $\mathrm{NaCl}$ in ancient DNA extraction. Although it yielded as good or even better results than GuSCN (Table 5) in some trials (data not shown), it had a tendency to co-purify large amounts of PCR inhibitors, an effect also reflected in the results of the final comparison, making it unsuitable for routine use with ancient DNA. However, in silica- based DNA purification processes that neither encounter large amounts of PCR inhibitors nor require the denaturing effect of chaotropic salts, the reason these salts were initially chosen for DNA extractions from agarose gels (26), $\mathrm{NaCl}$ could serve as a cheap alternative to chaotropic salts, a use previously proposed for plasmid (27) as well as for genomic DNA purification (28). The higher copy numbers achieved by washing the silica pellet twice with New Wash solution compared with washing it only once could be explained by a better removal of salt from the silica pellet. Consistent with earlier publications (21), the $\mathrm{pH}$ of the binding buffer had a significant effect on DNA recovery (Figure 2). The larger binding surface could explain the improved performance obtained by using more silica suspension. Thus, as the number 
of silica particles increases, the likelihood that DNA absorbs or binds with silica also increases.

In the final comparison using eight samples in duplicate and six different extraction methods, the modified silica method (method C) gave, on average, almost 2-fold higher DNA yields using quantitative PCR than the second best protocol (unmodified silica-GuSCN extraction; method A, Figure 3) (5). Low yields in the quantitative comparison may either indicate low amounts of template DNA or high amounts of inhibition. The latter explanation may explain the poor performance of method $\mathrm{B}$ (modified silica- $\mathrm{NaCl}$ extraction) in the quantitative comparison (see Supplementary Tables S17 and S18). In contrast, a lower amount of template DNA likely explains the lower yields resulting from method $\mathrm{A}$ versus $\mathrm{C}$, because in these two methods, the binding salt is identical, but the digestion buffer differs. The amount of inhibition, however, is similarly low in both methods. The concentration of inhibitory substances on the spin columns (as shown for six out of the eight samples) and the use of only the protein pellet following decalcification may explain the low yields of the widely used method $\mathrm{D}$ (8). As shown by Prado et al. (13), using pellet and supernatant together can double DNA yields, supposedly because during decalcification of the material, DNA bound to hydroxyapatit is released and accumulates in the EDTA. Similar results are reported in another publication (29) in which it was shown that in the case of a preliminary decalcification with $0.5 \mathrm{M}$ EDTA, the amount of retrievable DNA was always smaller than when this preliminary step was omitted.

Although similar results found elsewhere (22) indicate that our results could possibly be generalized for all types of bone samples used in ancient DNA analysis, a note of caution is warranted. In the current analysis, we only used bone and teeth taken from one species and from similar taphonomic contexts, namely cave sites with moderate climates. While our experience using this method in our laboratory has been positive, even with samples from different taphonomy such as permafrost, we did not perform systematic comparisons for samples from differing origins. DNA preservation, as well as the type of inhibitory substances, may vary in samples from different taphonomies such as permafrost, open sites (rather than caves), or warmer climates; thus, other methods may perform better on such samples. This problem is even more serious for samples of a completely different nature, such as sediment or feces, for which very different extraction methods are used. In our view, this limitation of the current study even more emphasizes the need for empirical data, which are, apart from the current study, almost completely lacking.

In summary, we found that most reagents routinely added to ancient DNA extraction buffers have no positive, and often have even an adverse effect on DNA yields. By optimizing each step in the extraction process, we have developed a method that produces higher DNA yields than published methods, while at the same time is comparatively quick (DNA extracts are obtained within 2 working days) and not very labor-intensive. We also show that the addition of BSA and the correct choice of DNA polymerase substantially influence amplification success. Taken together, our results provide a solid working protocol for future ancient DNA studies. At the same time, we hope that the current study encourages further work on this topic using samples of different types and taphonomic origin.

\section{ACKNOWLEDGMENTS}

We thank two anonymous reviewers for helpful comments, Susan E. Ptak for help with statistical analysis, the Molecular Ecology Group and Christine Green for helpful input, and Dominique Quinque and Birgitt Nickel for help with the human quantitative PCR assay. This work was funded by the Max Planck Society.

\section{COMPETING INTERESTS STATEMENT}

The authors declare no competing interests.

\section{REFERENCES}

1.Higuchi, R., B. Bowman, M. Freiberger, O.A. Ryder, and A.C. Wilson. 1984. DNA sequences from the quagga, an extinct member of the horse family. Nature 312:282-284.

2. Pääbo, S., H. Poinar, D. Serre, V. JaenickeDespres, J. Hebler, N. Rohland, M. Kuch, J. Krause, et al. 2004. Genetic analyses from ancient DNA. Annu. Rev. Genet. 38:645-679.

3. Noonan, J.P., M. Hofreiter, D. Smith, J.R. Priest, N. Rohland, G. Rabeder, J. Krause, J.C. Detter, et al. 2005. Genomic sequencing of Pleistocene cave bears. Science 309:597599.

4. Poinar, H.N., C. Schwarz, J. Qi, B. Shapiro, R.D. Macphee, B. Buigues, A. Tikhonov, D.H. Huson, et al. 2006. Metagenomics to paleogenomics: large-scale sequencing of mammoth DNA. Science 311:392-394.

5. Hofreiter, M., G. Rabeder, V. JaenickeDespres, G. Withalm, D. Nagel, $M$. Paunovic, G. Jambresic, and S. Pääbo. 2004. Evidence for reproductive isolation between cave bear populations. Curr. Biol. 14:40-43.

6.Höss, M. and S. Pääbo. 1993. DNA extraction from Pleistocene bones by a silica-based purification method. Nucleic Acids Res. 21:3913-3914.

7. Kalmar, T., C.Z. Bachrati, A. Marcsik, and I. Rasko. 2000. A simple and efficient method for PCR amplifiable DNA extraction from ancient bones. Nucleic Acids Res. 28:E67.

8. Leonard, J.A., R.K. Wayne, and A. Cooper. 2000. Population genetics of ice age brown bears. Proc. Natl. Acad. Sci. USA 97:16511654.

9. Yang, D.Y., B. Eng, J.S. Waye, J.C. Dudar, and S.R. Saunders. 1998. Technical note: improved DNA extraction from ancient bones using silica-based spin columns. Am. J. Phys. Anthropol. 105:539-543.

10. Hänni, C., T. Brousseau, V. Laudet, and D. Stehelin. 1995. Isopropanol precipitation removes PCR inhibitors from ancient bone extracts. Nucleic Acids Res. 23:881-882.

11. Bouwman, A.S. and T.A. Brown. 2002 Comparison between silica-based methods for the extraction of DNA from human bones from 18th to mid-19th century London. Anc. Biomol. 4:173-178.

12. Hummel, S. 2003. aDNA extraction, p. $57-$ 63. In Ancient DNA Typing. Springer Verlag, Berlin.

13.Prado, M., C.M. Franco, C.A. Fente, A. Cepeda, B.I. Vazquez, and J. BarrosVelazquez. 2002. Comparison of extraction methods for the recovery, amplification and species-specific analysis of DNA from bone and bone meals. Electrophoresis 23:10051012.

14.Pääbo, S., J.A. Gifford, and A.C. Wilson. 1988. Mitochondrial DNA sequences from a 7000-year old brain. Nucleic Acids Res 16:9775-9787.

15. Kurten, B. 1976. The Cave Bear Story. Columbia University Press, New York.

16. Pruvost, M. and E.-M. Geigl. 2004. Realtime quantitative PCR to assess the authenticity of ancient DNA amplification. J. Archaeol. Sci. 31:1191-1197.

17. Poinar, H.N., M. Hofreiter, W.G. Spaulding, P.S. Martin, B.A. Stankiewicz, H. Bland, R.P. Evershed, G. Possnert, et al. 1998 . Molecular coproscopy: dung and diet of the extinct ground sloth Nothrotheriops shastensis. Science 281:402-406. 


\section{Research Reports}

18. Hofreiter, M., C. Capelli, M. Krings, L. Waits, N. Conard, S. Münzel, G. Rabeder, D. Nagel, et al. 2002. Ancient DNA analyses reveal high mitochondrial DNA sequence diversity and parallel morphological evolution of late pleistocene cave bears. Mol. Biol. Evol. 19:1244-1250.

19. Krings, M., A. Stone, R.W. Schmitz, H. Krainitzki, M. Stoneking, and S. Pääbo. 1997. Neandertal DNA sequences and the origin of modern humans. Cell 90:19-30.

20. Boom, R., C.J. Sol, M.M. Salimans, C.L. Jansen, P.M. Wertheim-van Dillen, and J. van der Noordaa. 1990. Rapid and simple method for purification of nucleic acids. J. Clin. Microbiol. 28:495-503.

21. Melzak, K., C. Sherwood, R. Turner, and C. Haynes. 1996. Driving forces for DNA adsorption to silica in perchlorate solutions. $\mathrm{J}$. Colloid Interface Sci. 181:635-644.

22. Evison, M., D. Smillie, and A. Chamberlain. 1997. Extraction of single-copy nuclear DNA from forensic specimens with a variety of postmortem histories. J. Forensic Sci. 42:1032-1038.

23. Rogaev, E.I., Y.K. Moliaka, B.A. Malyarchuk, F.A. Kondrashov, M.V. Derenko, I. Chumakov, and A.P. Grigorenko. 2006. Complete mitochondrial genome and phylogeny of Pleistocene mammoth Mammuthus primigenius. PLoS Biol. 4: e73.

24. Krings, M., C. Capelli, F. Tschentscher, H. Geisert, S. Meyer, A. von Haeseler, K. Grossschmidt, G. Possnert, et al. 2000. A view of Neandertal genetic diversity. Nat. Genet. 26:144-146.

25. Fujiwara, M., F. Yamamoto, K. Okamoto, K. Shiokawa, and R. Nomura. 2005. Adsorption of duplex DNA on mesoporous silicas: possibility of inclusion of DNA into their mesopores. Anal. Chem. 77:8138-8145.

26. Vogelstein, B. and D. Gillespie. 1979. Preparative and analytical purification of DNA from agarose. Proc. Natl. Acad. Sci. USA 76:615-619.

27. Lakshmi, R., V. Baskar, and U. Ranga. 1999. Extraction of superior-quality plasmid DNA by a combination of modified alkaline lysis and silica matrix. Anal. Biochem. 272:109-112.

28. Prodelalova, J., B. Rittich, A. Spanova, K. Petrova, and M.J. Benes. 2004. Isolation of genomic DNA using magnetic cobalt ferrite and silica particles. J. Chromatogr. A. 1056:43-48.

29. Zoledziewska, M., S. Gronkiewicz, and T. Dobosz. 2002. Comparison of various decalcificators in preparation of DNA from human rib bones. Anthropologogical Rev. 65:75-80.

Received 12 June 2006; accepted 24 October 2006.

Address correspondence to Nadin Rohland, Max Planck Institute for Evolutionary Anthropology, Deutscher Platz 6, D-04103 Leipzig, Germany. e-mail: rohland@eva.mpg.de

To purchase reprints of this article, contact: Reprints@BioTechniques.com 